\title{
金属板上のポリ塩化ビニルの光劣化におよぼす 外部污染の効果
}

\author{
沖 慶雄* . 森 文雄 ${ }^{*}$. 田中厚夫 ${ }^{* *}$
}

\section{Effects of External Contamination on Photodegradation of Polyvinyl Chloride \\ Yoshio OKI, Fumio MORI and Atsuo TANAKA}

Effects of external contamination on photodegradation of polyvinyl chloride was studied by infrared spectrophotometry and observation of molecular weight change.

Staining materials used were 3 kinds of metal powders, 5 kinds of metal chlorides, and 2 kinds of metallic oxides.

$\mathrm{Fe}, \mathrm{Pb}$, and $\mathrm{Zn}$ powders showed great effects on photodegradation of polyvinyl chloride by means of infra-red absorption of carbonyls, which is an indicator of photodegradation.

Metal chlorides showed effects similar to those of metal powders, but the effects of metallic oxides were slightly different from others.

Iron and zinc oxides showed rapid increase of carbonyl absorption of polyvinyl chloride during initial stage of accelerated test by weathermeter, but tended to saturation in a long term weathering test.

In conclusion, the effects of external contamination of metal powders and metal chlorides on polyvinyl chloride were proved to be important factors for improving its weather-proof property.

\section{1. 緒言}

ポリ塩化ビニルと金属板が複合されて屋外で長期にわ たり用いられた場合，金属板とポリ塩化ビニルの光劣化 に対する相互作用について，下地金属板の紫外光反射の 作用は思ったほど大きくはなかった1〉。また実際には下 地金属板から表面のポリ塩化ビニル皮膜の中に移行して きた金属イオンが，光と酸素の存在でポリ塩化ビニルの 光酸化分解を促進する作用をすることが，下地金属の光 に対する反射より著しく大であると報告2゙した。

本報に打いて複合の代表として取り上げたポリ塩化ビ ニルのような有機皮膜は，実用上，ほとんどといってよ いほど，その使用の環境，ふ九囲気にさらされるのは有 機皮膜の最外層である。

いまをでポり塩化ビニルの光劣化に打よぼす，各種金

* 東洋製缶・東洋鋼鈑綜合研究所（神奈川県横浜市保 土ケ谷区岡沢町22-4)

The Composite Research and Development Center of TOYOSEIKAN and TOYO KOHAN Cos.

** 東洋鋼鈑下松工場研究所 (山口県下松市東豊井) Kudamatsu Plant Laboratory of TOYO KOHAN Co.
属酸化物, 塩化物の混入に上る報告 ${ }^{33,4)}$ がなされている が，実用上からは有機皮膜に混入污染というのは，なん らかの目的での添加物を除いては, 非常に少ないるの でこのよらな污染はほとんど外部からるたらされるる のである。

たとえば土中に埋没した場合，古材木と接触している 場合, 海岸地带の海塩の作用，など污染は外部よりもた らされるすのである。

もっとも代表的な例を写真 1 に示した。これはポり塩 化ビニルの表面に指紋の污染があったるのを促進試験に よって, 指紋部のポリ塩化ビニルが分解し, 明りょうに

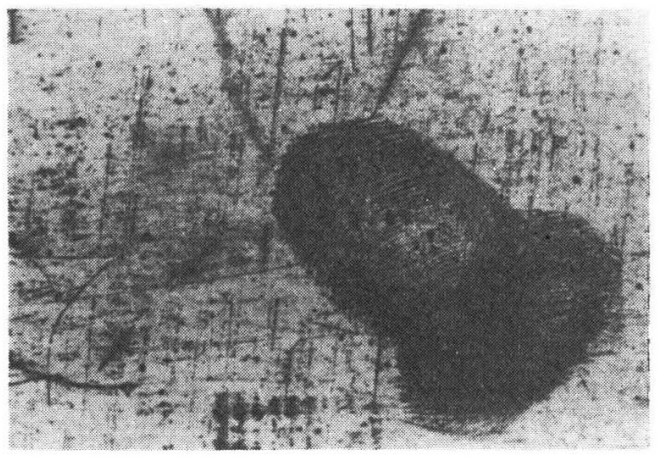

写真 1 指紋によるポリ塩化ビニルの光劣化 


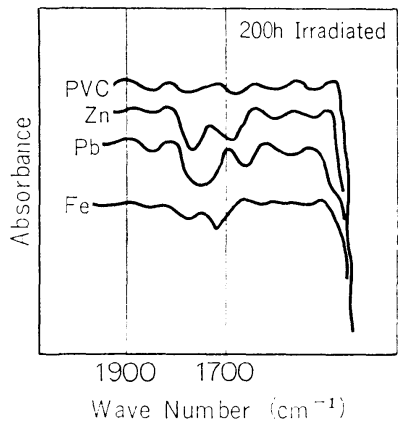

図 1 金属粉末塗布 PVCフィルムの 促進試験後の赤外吸収スペクトル

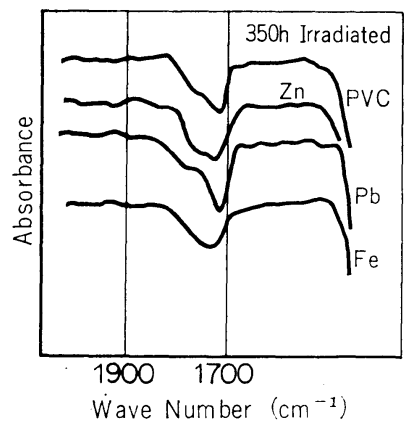

图 2

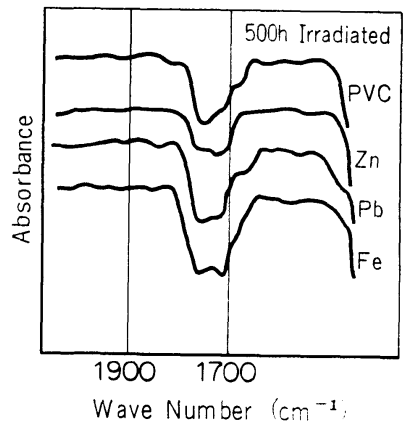

図 3
肉眼で見えるようになったものである。

それゆ充本報ではいままで光劣化に対する考察として 内部污染の作用がなされたのに対し, 各種金属塩化物を 用いての外部污染の作用を検討したので報告する。

\section{2. 実験方法}

\section{2-1 実験試料}

実験に用いたポリ塩化ビニル（以下，PVC）は前報2 ごとく, 市販の Geon 103EP-8（ $\mathrm{p}=1050 ）$ を用い溶郕と のしてテトロヒドロフラン (THF) に溶解させ, 厚サ $25 \mu$ になるように流ゼンしたのち真空乾燥器中で溶剤を除去 し，さらに PVC と結合しているテトロヒドロフランを 除去するためエチルエーテルで洗い，テトロヒドロフラ ンの特性吸収のないことをしらべたのちに実験材料とし た。

このようにして作製した PVC の片面に，つぎに示す 各種金属粉末, 塩化物を塗布し, 別に用意した PVC フ ィルムを重ね，周囲をとートシールし，塗布粉末の脱落 を防止したのち，表面污染のないように，エーテルにて ぬぐい実験試料とした。

\section{2-2 金属粉末, 金属塩化物}

金属粉末，金属塩化物ともに市販の試薬特級を用い

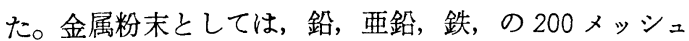
通過分を用い，金属塩化物としては $\mathrm{BaCl}_{2}, \mathrm{CdCl}_{2}$, $\mathrm{PbCl}_{2}, \mathrm{ZnCl}_{2}$ ，また酸化物として $\mathrm{ZnO}, \mathrm{Fe}_{2} \mathrm{O}_{3}$ を用い た。

\section{2-3 光照射方法}

光促進劣化試験機として，サンシャインカーボンアー クを光源として用いた。

\section{2-4 カルボニルの定量}

一定時間ごとに取りだした試料の両面について，赤外 分光光度計により, 吸光度比 $\mathrm{D}_{1725} / \mathrm{D}_{2930}$ の变化を求め た。

\section{2-5 平均分子量の測定}

一定時間ごとに取りだした試料を JIS K-6721 の塩化
ビニル樹脂試験法にしたがい， Ubbelohde の粘度計に より比粘度を測定し，次式により極限粘度を求わたの ち, 平均重合度を算出した。

$[\eta]=\frac{\sqrt{2}}{C} \cdot \sqrt{\eta s p-\log e \eta r e l}$

$[\eta]$ ：極限粘度, $\eta r e l:$ 相対粘度 $\left(t_{2} / t_{1}\right)$

$\eta s p:$ 比粘度, $\quad C:$ 濃度 $(\mathrm{g} / l)$

$\bar{p}=500\left\{\right.$ anti $\left.\log _{10} \frac{[\eta]}{0.168}-1\right\}, \bar{p}:$ 平均重合度

\section{3. 実験結果と考察}

\section{3-1 金属粉による PVC の光劣化}

金属粉末を塗布して，促進試験を行なった試馻フィル ムを一定時間ごとに取りだし，塗布してある金属粉末を 水洗によって取り除き, その後, 真空乾燥器で乾燥した のち, カルボニルの生成をみるために, 赤外四収スペク トルを測定した。

測定は促進試験機の照射時間 $200 \mathrm{~h}, 350 \mathrm{~h}, 500 \mathrm{~h}$, $750 \mathrm{~h} ， 1,000 \mathrm{~h}$ になるようにして行なった。

各試験フィルムの赤外吸収スペクトルは図1～図 5 に 示した。

図中 PVC とあるのは, 無塗布の PVC フィルムで, 外部污染のないものでュントロールとして用いた。

この結果からは，いままで PVCなどの劣化を促進す る作用を示す物質は，なんらかの原因によりポリマー中 に存在することが必要な劣化促進のように思われていた が，ここで用いた金属粉末乞のるのが，光の照射される 裏面にあったとしてる，著しい劣化の促進作用を示した ことは注目されることであった。

$1725 \mathrm{~cm}^{-1}$ の吸収のみで，ポリマーが著しい劣化をう

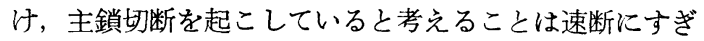
るので, さらにこれらのフィルムの分子量の変化を合わ せて検討し, カルボニルの吸収が増觉，かつ分子量低下 がみられるとするならば，明らかに少化の進行があるも のと考えられる。 


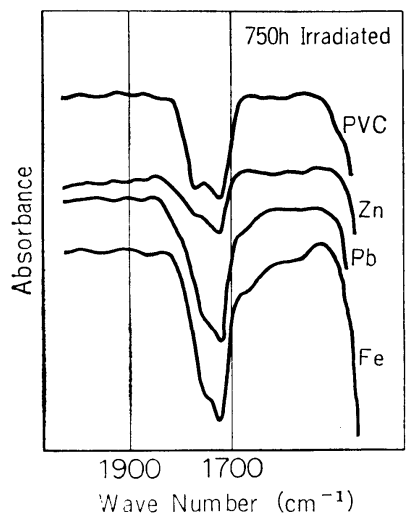

図 4

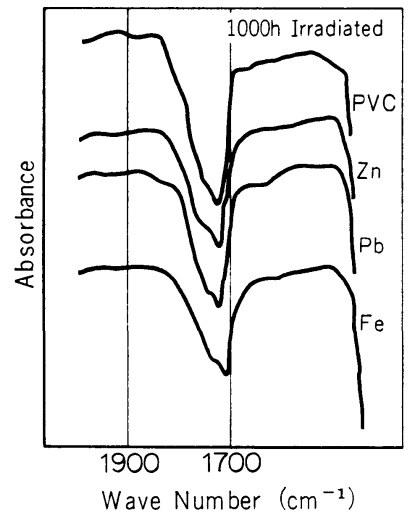

图 5

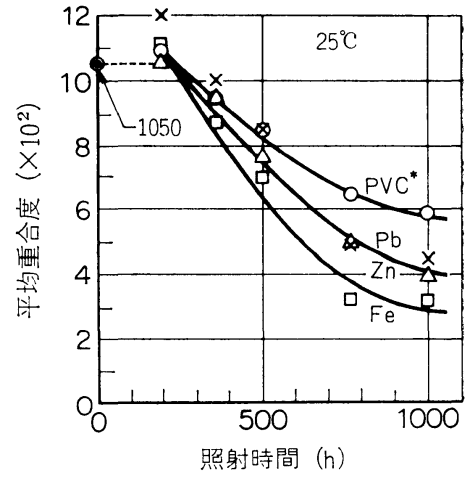

PVC : なにも塗布せず

$\mathrm{Pb}, \mathrm{Zn}, \mathrm{Fe}$ : それぞれ粉末を PVC の裏面に塗布 図 6 促進試験後の平均重合度の変化

促進試験機のふん囲気温度が異なれば，劣化の程度も 異なるので, 本実験では $25^{\circ} \mathrm{C}$ になるようにして行なっ た。

結果を図 6 に示した。

試験に用いた PVC の平均重合度は1050であったが， $200 \mathrm{~h}$ の照射によって重合度の増加傾向が 各試料ともに みられるが，これは PVC 中のターシャリ炭素による不 安定構造に基づく脱塩化水素とともに生ずる架橋構造に よるるのと推定される。

いったん架橋が起こっても，各金属の接触触媒作用が なくなることはないらえに，一部に生成が推定される金 属カルボニル, ポリマーキレート化合物は, 光劣化にあ

たっては金属そのものよりも，劣化分解に大きく作用す ると考えられる。

図 6 ではほぼ $750 \mathrm{~h}$ までは急速に平均分子量が低下す る。

鉄粉は約 $\overline{\mathbf{p}}: 400$, 鉛, 亜鉛粉は約 $\overline{\mathrm{p}}: 500$, 無塗布の 場合 $\overline{\mathrm{p}}: 650$ となり，鉄粉の作用の大きなことが比較に より明りょらである。

また $1,000 \mathrm{~h}$ の照射では劣化の進行は緩やかとなり， 飽和するように見觉る。

赤外スペクトルとの照合において，さらに劣化の進行 の形態に典形的なタイプのあることが，表 1 および図

表 1 金属粉, 金属塩化物塗布 PVCフィルムの赤外吸収スペクトルの吸光度比

\begin{tabular}{|c|c|c|c|c|c|c|c|c|c|c|}
\hline 金属亡金属塩化物 & $200 \mathrm{~h}$ & 順位 & $350 \mathrm{~h}$ & 順位 & $500 \mathrm{~h}$ & 順位 & $750 \mathrm{~h}$ & 順位 & $1,000 \mathrm{~h}$ & 順位 \\
\hline $\mathrm{Fe}$ & 0.028 & 6 & 0.090 & 9 & 0.103 & 7 & 0.310 & 9 & 0.324 & 9 \\
\hline $\mathrm{Pb}$ & 0.017 & 4 & 0.084 & 8 & 0.144 & 8 & 0.165 & 6 & 0.299 & 8 \\
\hline $\mathrm{Zn}$ & 0.040 & 8 & 0.055 & 4 & 0.065 & 2 & 0.165 & 6 & 0.228 & 5 \\
\hline $\mathrm{FeCl}_{3}$ & 0.027 & 5 & 0.053 & 3 & 0.087 & 4 & 0.115 & 2 & 0.195 & 3 \\
\hline $\mathrm{BaCl}_{2}$ & 0.011 & 2 & 0.053 & 3 & 0.098 & 6 & 0.152 & 5 & 0.282 & 7 \\
\hline $\mathrm{CdCl}_{2}$ & 0.034 & 7 & 0.055 & 4 & 0.088 & 5 & 0.144 & 4 & 0.215 & 4 \\
\hline $\mathrm{PbCl}_{2}$ & 0.044 & 9 & 0.071 & 6 & 0.080 & 3 & 0.168 & 7 & 0.249 & 6 \\
\hline $\mathrm{ZnCl}_{2}$ & 0.053 & 10 & 0.064 & 5 & 0.164 & 9 & 0.128 & 3 & - & \\
\hline $\mathrm{ZnO}$ & 0.040 & 8 & 0.075 & 7 & 0.144 & 8 & 0.175 & 8 & 0.216 & 4 \\
\hline $\mathrm{Fe}_{2} \mathrm{O}_{3}$ & 0.012 & 3 & 0.034 & 2 & 0.198 & 10 & 0.175 & 8 & 0.195 & 2 \\
\hline 無 乙 & 0.010 & 1 & 0.025 & 1 & 0.044 & 1 & 0.114 & 1 & 0.194 & 1 \\
\hline
\end{tabular}

* 順位はカルボニルの吸収の少ない順に 1 から10までつけた。

** 吸光度比は $\mathrm{D}_{1725} / \mathrm{D}_{2930}$

*** サンシャインウエザーメータ促進試験後に測定 


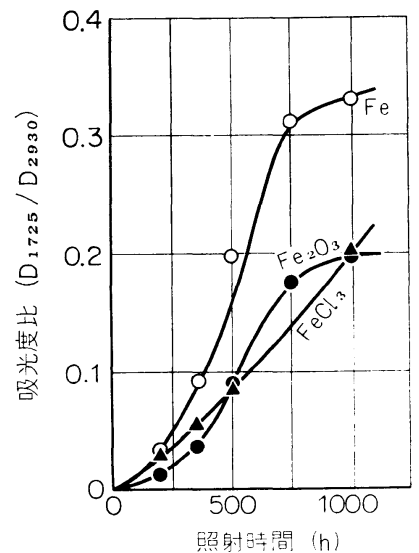

\section{7, 図8からわかる。}

すなわち鉄粉の場合はカルボニルの吸収は初期に执い て急速に増加し，あとはゆるやかになるが，分子量低下 は必ずしも緩やかではない。

亜鉛，鉛粉は，初期から急速にカルボニルの吸収が増 加し，平衡に達するようには見られないが，分子量の低 下は鉄粉の場合より少ない傾向がある。

\section{3-2 酸化物, 塩化物の作用}

結果は表 1 にまとめて示したが，用いた塩化物の中で は, 一般に PVC の安定剤として用いられているバリウ ム，カドミウム，鉛，亜鉛は塩化物として PVC の表面 に付着しただけで，いずれも著しい劣化を生ずる。

とくに $\mathrm{FeCl}_{3}, \quad \mathrm{ZnCl}_{2}$ の影響ははなはだしく, $100 \mathrm{~h}$ の照射でも変色をみとめるほどであった。

外観の比較では $\mathrm{BaCl}_{2}, \mathrm{CdCl}_{2}$ は前者に比して影響は 少ないようであった。

また酸化物は試験が鉛，亜鉛，のみであったので十分 な比較は行なえなかったが, 両者とる, 初期のカルボニ ルの吸収は急速に增加するにるかかわらず，照射時間が $750 \mathrm{~h}$ をすぎるころより傾斜がゆるやかとなり，一定值 汇達する傾向をみせている。（図 7, 図 8）

\section{4. 結 論}

PVC の皮膜の表面に付着したような污染物質であっ

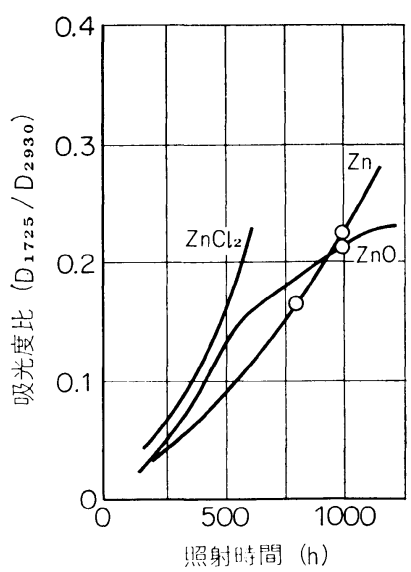

図 8 亜鉛化 合物塗布 の影響

ても，光劣化に対しては非常に劣化を促進する作用のあ るものが存在する。

本報飞招いては，金属粉末として鉄粉，鉛粉，亜鉛粉 を用いたがここれらはいずれも劣化の促進作用がみら れ，とくに鉄粉に执いてその作用が大きかった。

また塩化物としては塩化第一鉄, 塩化亜鉛の促進作用 が大きく, 酸化物となると, 初期の劣化進行の過程に打 いては，金属粉末，塩化物との間に大きな差はないが， 長時間の試験では促進作用が徐々に弱まる傾向を示して いる。

これはこれらの酸化物が着色しているため, 光の吸 収，励起に異なったプロセスをもつため，ポリマーの劣 化にも異なった作用があり，同一に評価することはでき ないことと考兄られる。 (1973-2-13 受理)

\section{文献}

1) 沖 慶雄, 森 文雄, 本誌, 23, 609 (1972)

2) 沖 慶雄, 森 文雄, 杉本義之, 本誌, 24, 87 (19 73)

3) A. Reiche, A. Grimm, H. Hücke, Kunststoffe, 52, 265, 398 (1962)

4) L. H. Wartman, Ind. Eng. Chem., 47, No. 5, 1013 (1955) 